\title{
PERFORMANCE STUDY OF A CI ENGINE FUELLED WITH KEROSENE AND RAW CARDANOL BLENDS
}

\author{
RAVINDRA $^{1 *}$, M. ARUNA ${ }^{2}$, HARSHA VARDHAN ${ }^{3}$ \& DILIP KUMAR K ${ }^{4}$ \\ ${ }^{1,4}$ Department of Mechanical Engineering, NMAM Institute of Technology, NitteVTU Belagavi, India \\ ${ }^{2,3}$ Department of Mining Engineering, National Institute of Technology Karnataka, Surathkal, India
}

\begin{abstract}
Biofuel is a renewable source of energy and an alternative to fossil fuels. Cardanol is one such biofuel, which was already blended up to $20 \%$ with diesel and tested in diesel engines by various researchers. In this study, raw Cardanol blends with kerosene were prepared and its performance study is carried out in a 4-Stroke CI Engine. The kerosene and Cardinol blends were prepared by varying the kerosene percentage from $10 \%$ to $40 \%$ by volume. It was observed from the results that, the performance of $\mathrm{BK}-30$ blend was similar to diesel fuel. Brake thermal efficiency was only $1.5 \%$ lesser to that of neat diesel at peak load. Emissions of CO, HC and smoke were declined by $42.6 \%, 5.08 \%$ and $1.8 \%$, respectively when compared to neat diesel. However, NOx was increased by $1.9 \%$. It is been observed from the study that the BK-30 blend can be an alternative for CI engine fuel.
\end{abstract}

KEYWORDS: Performance, Exhaust gas emission, Biofuel \& Brakes thermal efficiency

Received: Jun 06, 2020; Accepted: Jun 26, 2020; Published: Jul 03, 2020; Paper Id.: IJMPERDJUN2020180

\section{INTRODUCTION}

The world-wide attention is towards the problems of climatic changes due to environmental pollution. The key contributor to pollution is higher usage of fossil fuels that is about $80 \%$ of world's energy needs. The use of fossil fuel in engines and power plants emits pollutants like oxides of nitrogen $\left(\mathrm{NO}_{\mathrm{x}}\right)$, particulate matter, sulphur dioxide $\left(\mathrm{SO}_{2}\right)$, carbon dioxide $\left(\mathrm{CO}_{2}\right)$, carbon monoxide $(\mathrm{CO})$, unburned hydrocarbon $(\mathrm{HC})$ etc. These pollutants are harmful to the human beings and the nature, which may cause various environmental hazards such as global warming, acid rains, abrupt changes in climate, depletion of ozone layer, photochemical smog etc. [1].

Though very stringent regulations of emissions were set by the governments to minimise pollution, the energy requirement is moving in upward direction day by day. To overcome these constraints there is a need for alternative fuel with less pollution and renewable in nature. Most of the researchers in, this area are focusing on biofuels that is the fuels extracted from vegetable or animal oils. The ethyl or methyl esters of these oils are called as biodiesels which is used as a fuel in diesel engines [2]. Biodiesels has been extracted from various feedstocks, such as Jatropa, Sunflower oil, Waste cooking oil, Linseed oil, Pongamia, Mahua oil, Fish oil, Ox tallow etc. These biodiesels blended with neat diesel fuel were tested in compression ignition engines by the earlier researchers.

Behcet et al, [3] have produced two varieties of biodiesels -one from waste cooking oil and another from fish oil. These biodiesels were tested in compression ignition engines. Diesel blends with $25 \%$ biodiesel (i.e. $25 \%$ fish oil biodiesel - FB25 and 25\% waste cooking (WCO) oil biodiesel - CB25) were used in the engine and notified that $\mathrm{HC}$ and $\mathrm{CO}$ emissions were lower than the neat diesel. The smoke discharges were reduced by $15.36 \%$ and 7.81\% respectively for FB25 and CB25, when compared to neatdiesel. Godiganur et al. [4] have tested fish oil 
methyl esters in a Kirloskar HA394 engine and stated that there is drop in $\mathrm{HC}$ and $\mathrm{CO}$ releases. Ozer Can [5] prepared the blends of 5\% and 10\% waste cooking (WCO) oil biodiesel with diesel and operated a diesel engine by using these blends. He found that there is an increase in brake specific (bsfc) fuel consumption up to $4 \%$ and decrease in brake thermal(BTE) efficiency up to $2.8 \%$ by blending of biodiesel. Smoke and HC releases were decreased at all the loads. Suresh Kumar et al, [6] have studied pongamia pinnata methyl ester as a fuel in a diesel engine and understood that up to $40 \%$ blend can be used in the engines with better performance and emissions matched to neat diesel fuel.

The performance and emissions depends on the feed stock from which the biodiesels were produced. The above studies also revealed that in general, there was reduction in pollutant emissions by using biodiesels. The biofuel feed stock used for production of biodiesel must be easily available at low cost. As per literature review the cashew nut shell liquid is the cheapest feedstock for diesel engines. Because cashew nut trees are abundantly grown in countries like India, Malaysia, Brazil, Senegal, Africa, Madagascar and Kenya. The cashew nut shell liquid was blended with diesel and its performance was investigated by many researchers. Mallikappa et al, [7] determined the performance and the emissions of twin cylinder CI engine run with Cardanol and diesel blends and found that the brake specific energy consumption reduced by approximately 30-40 \% with increase in brake power. Cardanol being a by-product of cashew nut processing it costs less and is available in abundance, as discussed earlier. They also concluded that up to $20 \%$ blend of cardanol biofuels the diesel engine needs no modification. The findings of many other works in this area also support this. For example Santhanakrishnan and Ramani [8] have evaluated the compression ignition engine performance with diesel cashew nut(CNSO) shell oil blends in a four stroke compression ignition engine and realised that the maximum brake thermal (BTE) efficiency was limited to $20.4 \%$ for CNSO and $30.8 \%$ for diesel fuel. It is been found that specific fuel(sfc) consumption, exhaust gas(EGT) temperature, $\mathrm{HC}, \mathrm{CO}, \mathrm{NOx}$ and smoke emissions increases with rise in CNSO blend. A good performance of engine was observed for $20 \%$ CNSO blend. Azad et al, [9] have used diesel blends with raw mustard oil in CI engine and recorded a lower brake specific fuel (BSFC) consumption and higher thermal (BTE) efficiency related to neat diesel. Aydin et al, [10] investigated air cooled 4-stroke CI engine performance with different blends of cotton seed oil and kerosene and found that $80 \%$ bio diesel and $20 \%$ kerosene blend shows a better performance than other blends. Further, NOx and CO emissions are lower and MEP (mean effective pressure) and BTE are high for this blend.

In this Investigation blends of raw Cardanol and kerosene were used in a water cooled four stroke diesel engine to evaluate its performance and emissions. Since Cardanol does not yield glycerol during esterification, it was decided to use raw Cardanol. In most of the biofuels methanol was used to reduce its viscosity. But the adding of methanol reduces the calorific (CV) value of that biodiesel. Hence, in this work kerosene was used to reduce the viscosity of biofuel. This also acts as fuel with vigorous burning so that higher percentage of Cardanol can be blended.

\section{MATERIALS AND METHODS}

\section{Preparation of Test Fuel}

The Cardanol and kerosene were mixed on volume basis. Cardanol was purchased from local cashew factory, and diesel and kerosene from local outlets. Different blends of Cardanol and kerosene, such as BK-10 (10 \% kerosene, BK-20 (20\% kerosene), BK-30 (30 \%), BK-40 \% (40\% kerosene) were used. The blends were checked for miscibility by keeping it for two days. Properties like calorific (CV) value, flash point, kinematic viscosity and density, of diesel, kerosene, Cardanol and kerosene Cardanol blends were evaluated as per ASTM standards, the results of which are tabulated in Table.1. 
Table 1: Properties of Diesel, Kerosene, Cardanol and Blends

\begin{tabular}{|l|c|c|c|c|c|c|c|c|}
\hline \multicolumn{1}{|c|}{ Properties } & $\begin{array}{c}\text { ASTM } \\
\text { code }\end{array}$ & Diesel & Kerosene & Cardanol & BK10 & BK20 & BK30 & BK40 \\
\hline $\begin{array}{l}\text { Kinematic } \\
\text { viscosity } \\
\text { @ } 40^{\circ} \mathrm{C} \text { (in } \\
\mathrm{cSt} \text { ) }\end{array}$ & $\mathrm{D} 445$ & 3.17 & 1.18 & 19.4 & 14.2 & 9.3 & 5.9 & 3.8 \\
\hline $\begin{array}{l}\text { Density @ } \\
15^{\circ} \mathrm{C} \text { (in } \\
\mathrm{kg} / \mathrm{m}^{3} \text { ) }\end{array}$ & D1298 & 821 & 780 & 903 & 846 & 834 & 825 & 811 \\
\hline $\begin{array}{l}\text { Flash point } \\
\text { (in C) }\end{array}$ & D93 & 51 & 42 & 218 & 112 & 82 & 65 & 59 \\
\hline $\begin{array}{l}\text { Calorific } \\
\text { value } \\
\mathrm{kJ} / \mathrm{kg} \text { (in }\end{array}$ & $\mathrm{D} 240$ & 43580 & 44230 & 40246 & 40598 & 40960 & 41331 & 41712 \\
\hline
\end{tabular}
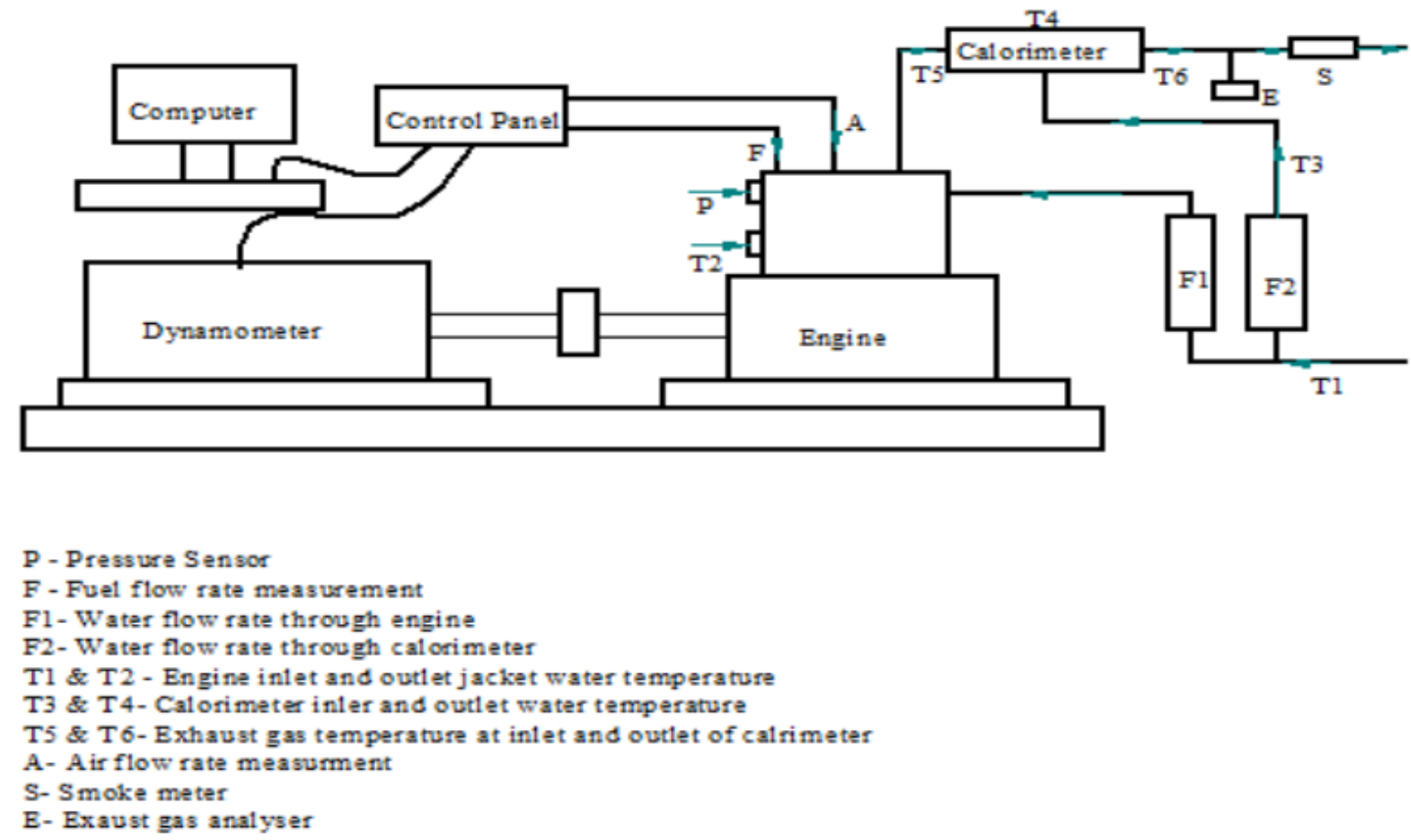

Figure 1: Experimental set up

\section{Experimental Test Rig and Procedure}

The investigational work was evaluated out in a single cylinder water cooled four stroke diesel engine run at $1500 \mathrm{rpm}$ and 17:1 compression ratio. The representative diagram of the test rig is shown in Fig.1. Theloading is using an eddy current dynamometer which is tied to the crankshaft. The capacity of dynamometer is of producing $7.5 \mathrm{~kW}$ and rated at a maximum speed of 3000rpm. The engine is interfaced with computer for data collecction. The specifications for engine used are indicated as shown in Table 2. 
Table 2: Technical Specifications of the Engine

\begin{tabular}{|l|c|}
\hline Number of cylinders & 1 \\
\hline Number of strokes & 4 \\
\hline Power & $3.5 \mathrm{~kW}$ \\
\hline Bore & $87.5 \mathrm{~mm}$ \\
\hline Stroke & $110 \mathrm{~mm}$ \\
\hline Rated speed & $1500 \mathrm{RPM}$ \\
\hline Connecting rod length & $234 \mathrm{~mm}$ \\
\hline Compression ratio & 12 to18:1 \\
\hline Dynamometer arm length & $184 \mathrm{~mm}$ \\
\hline Orifice diameter & $20 \mathrm{~mm}$ \\
\hline
\end{tabular}

The engine is checked and set before stating against the manufacturer specifications. The water movement rate through the calorimeter and engine were set to the catalogue values. The engine dual fuel tank was filled with diesel and a blend. The engine was warmed up to reach steady state by running with the same parameters for 15 to 20 minutes. After that load was applied by the dynamometer and the fuel consumption rate was recorded. The exhaust emissions was detected with the help of exhaust gas (Netel exhaust gas analyser, Model: NPM-MGA-1) analyser and the smoke denseness was measured with the help of a smoke meter Thermocouples were mounted for temperature measurement. While changing the blend the tank was fully drained and filled with test fuel. For every trail readings were recorded only after engine reaching the steady state (15 to 20 minutes). For all the test fuels brake thermal (BTE) efficiency, brake specific(BSFC) fuel consumption and exhaust(EGT) gas temperature readings have been noted.

\section{RESULTS AND DISCUSSIONS}

\section{Brake Thermal Efficiency}

Figure 2 illustrates the variations of BTE with load for diesel and different blends of kerosene and Cardanol. The BTE increment is noted with load for all the blends. This observation is because of drop in heat loss and friction to brake(BP)power ratio at higher loads.

The BTE increase with rise in kerosene percentage in the fuelblend up to $30 \%$.This is because of better atomisation and higher volatility of kerosene. Since kerosene is a dry fuel for BK-40 blend, the BTE reduces because of increased frictional loss at the pump. At highest load BTE for diesel fuel was $28.72 \%$ and for BK-30 it was $28.3 \%$. Among all the blends, higher BTE was obtained for BK-30. However, this is $1.5 \%$ less than diesel which may be due to drop in calorific (CV) value of the BK-30 blend compared to diesel. 


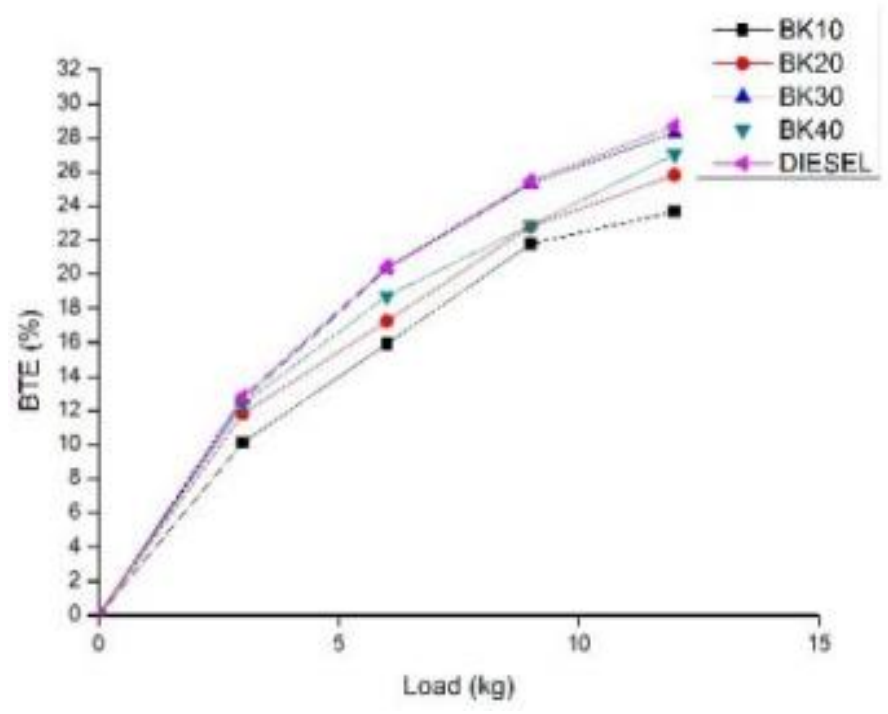

Figure 2: Variation of Brake Thermal Efficiency with Load.

\section{Brake specific fuel consumption:}

Brake specific (BSFC) fuel consumptionis the amount of fuel burned in the engine to produce unit power in unit time. Fig. 3 shows variation of BSFC with load for different blends and diesel. As shown in the figure, biofuel blends reports a higher BSFC than that of neatdiesel which may be due to lower calorific $(\mathrm{CV})$ value and higher density of biofuel blends. There was a reduction in BSFC as the percentage of kerosene increases.

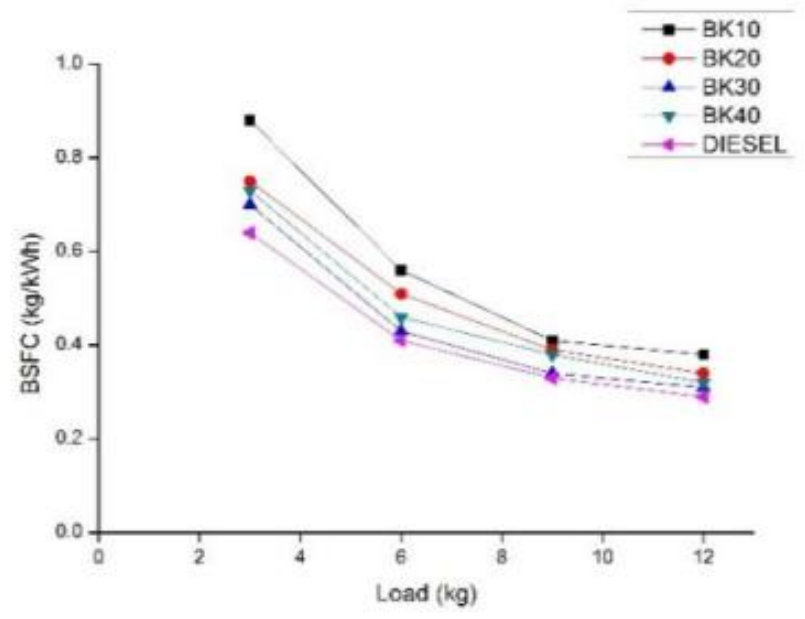

Figure 3: Variation of Brake Specific Fuel Consumption with Load.

\section{Exhaust Gas Temperature(EGT):}

The EGT variations for different test fuel blends at different loads were revealed in Fig. 4. Very high exhaust gas temperature (i.e. $297.42^{\circ} \mathrm{C}$ ) was observed for BK-10 blend. This is because of poor volatility and high viscosity of blend, which leads to incomplete combustion and extension of combustion to exhaust stroke. However, as a result of increased volatility and atomisation of blend for BK-20 and BK-30 blends, the exhaust gas temperature was reduced (i.e. $281.49^{\circ} \mathrm{C}$ and $274.96^{\circ} \mathrm{C}$ respectively). This is mainly due to improvement in combustion. For BK-40 blend the exhaust gas(EGT) temperature was again increased. For diesel fuel the exhaust gas temperature was $269.19^{\circ} \mathrm{C}$, which is lower than the blends tested. 


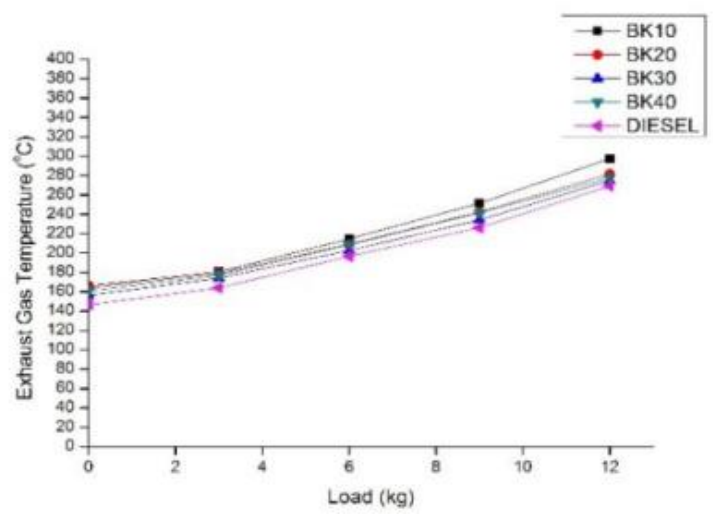

Figure 4: Variation of Exhaust Gas Temperature with Load.

\section{Carbon Monoxide}

Fig. 5 shows the deviation in CO production with load. Carbon monoxide emission was increasing with rise in load for diesel fuel. This is because of more fuel injection at higher loads [11]. For kerosene blends CO release was reduced with rise in load and increase in percentage of kerosene. This is essentially due to widespread combustion of blends due to higher volatility of kerosene. At full load for BK-10, BK-20, BK-30 and BK-40 blends CO emissions were respectively 37.8\%, $41.5 \%, 42.6 \%$ and $45.1 \%$, which is lesser than that of the neat dieselfuel.

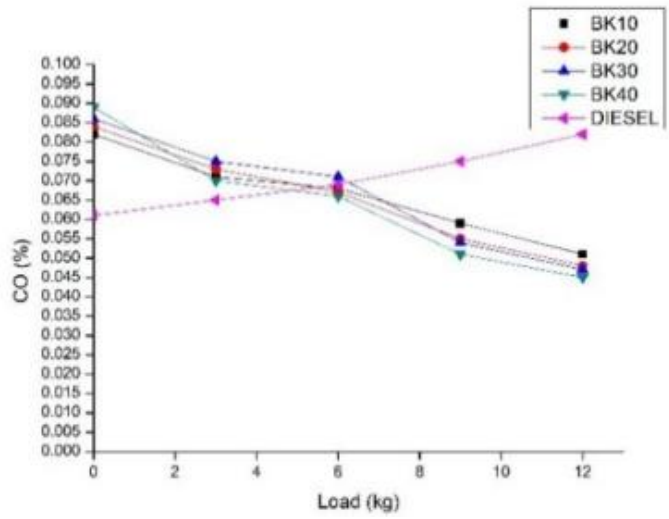

Figure 5: Variation of Carbon Mono oxide with Load.

\section{Unburned Hydrocarbon}

Fig. 6 displays unburned (HC) hydrocarbon releases at various loads. For the entire test fuels HC releases were increasing with upturn in load. Similarly, though at lower loads the HC emission was low for diesel, as the load increases emissions were also increasing. At higher loads higher percentage of kerosene in the blend caused in reduction in $\mathrm{HC}$ emission. At lower loads the $\mathrm{HC}$ emission for diesel is low in comparision with the test blends. Due to viscosity and incomplete combustion at full load for BK-10 blend emission was 5\% more than the diesel fuel. For BK-20, BK-30 and BK-40 blends HC emission was respectively 1.69\%, 5.08\% and 11.8\% less than diesel. This is because of higher volatility and fast burning of kerosene. 


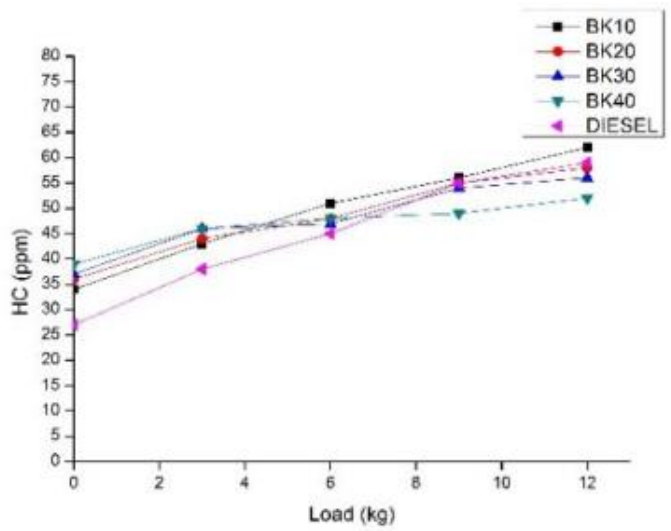

Figure 6: Variation of Unburned Hydrocarbon Emission with Load.

\section{Oxides of Nitrogen (NOx)}

Oxides of (NOx) nitrogen were evolved during combustion due to presence of higher concentration of oxygen in combustion chamber and high burning temperature. Fig.7 indicates the deviation of NOx releases at different loads. From the graph it is noticed that NOx emissions are increasing with rise in load for the fuels tested in the study. Similar variations were also described by Godigunar et al. [6]. Related to diesel fuel the releases of NOx emission increased by $30.8 \%, 24.4 \%, 1.9 \%$ and $2.6 \%$ for BK-10, BK-20, BK-30 and BK-40 blends respectively. This increase in NOx emission is mainly due to presence of inbuilt oxygen in the biofuel and also slow combustion of biofuel, which leads to rise in exhaust (EGT)gas temperature and NOx formation.

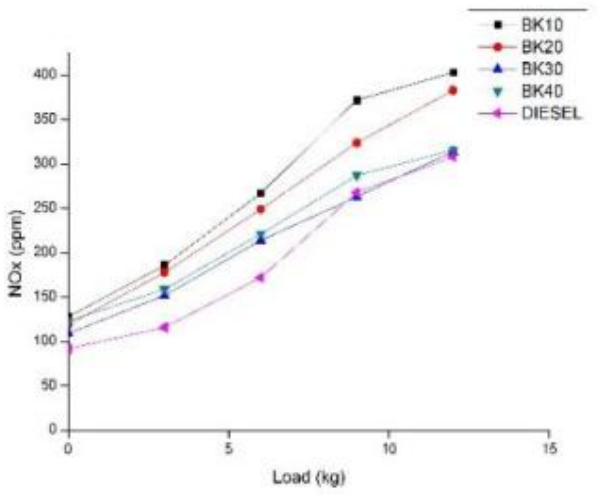

Figure 7: Variation of Oxides of Nitrogen Emission with Load.

\section{Smoke Emissions}

Figure 8 demonstrates the smoke emissions at different loads. The smoke emissions are increasing with increased load. Since more fuel is injected at higher load which leads to decrease in air (A/F)fuel ratio and some portion of fuel is exhausted in unburned state. For the biofuel blends used in this study smoke emissions were greater than neatdiesel at all the loads. It was observed from thefigurethat the smoke emissions reduce with increase in percentage of kerosene. For blends BK-10 and BK20 smoke emissions increased by $39.1 \%$ and $17.8 \%$ when matched to diesel. This is mainly due to poor combustion, because of higher viscosity of blend. However, in case of blends BK-30 and BK-40 smoke emissions decreased by $1.8 \%$ and $5.4 \%$ linked to diesel. The decrement in smoke releases is due to higher volatility of kerosene, by which combustion will be fast and complete. 


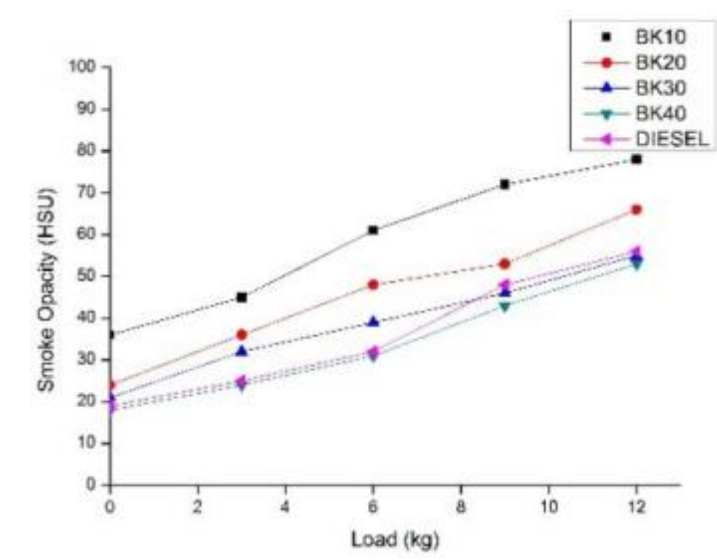

Figure 8: Variation of Smoke Emission with Load.

\section{CONCLUSIONS}

A diesel engine was functioned with Cardanol blends with $10 \%$ to $40 \%$ kerosene and its performance was related with that of diesel. The subsequent conclusions were obtained from the experimental results:

- By the addition of kerosene to Cardanol the viscosity and density of the blend was reduced with increase in its calorific value.

- BTE of BK-30 is only $1.5 \%$ less than that of diesel, which is comparable to diesel.

- For BK-30 blend the CO emissions and unburned $\mathrm{HC}$ were reduced by $42.6 \%$ and $5.08 \%$ respectively in comparision with diesel at full load.

- Smoke release was reduced by $3.5 \%$ for BK-30 blend at peak load w.r.t. diesel.

- There was a minor increase in NOx emission (by 1.95\%) is observed compared to fuel withought any blend.

The above findings demonstrate that BK-30 blend can become a substitute fuel forcompression ignition engines without much reformation.

\section{REFERENCES}

1. Sanjid, A., et al., "Production of palm and jatropha based biodiesel and investigation of palmjatropha combined blend properties, performance, exhaust emission and noise in an unmodified diesel engine", Journal of Cleaner Production, 65 (2013), pp.295-303.

2. Dinesha, P. and Mohanan, P. "Effect of Oxygen Enrichment of Intake Air on the Performance and Emission of Single Cylinder CI Engine Fuelled with Cardanol Blends", Distributed Generation \& Alternative Energy Journal, 30 (2015), 1, pp.6-14.

3. Shivaji, Kailash B. Anwar, and S. Gowreesh. "Experimental Investigation on Use of Preheated Pongamia Oil Bio-Diesel in DI Diesel Engine." International Journal of Automobile Engineering Research and Development (IJAuERD) 4.6 (2014): 1-6.

4. Behcet R., et al., "Effect of fuels produced from fish and cooking oils on performance and emissions of a diesel engine", Energy, 71 (2013), pp.645-655.

5. Godiganur S, et al., "Performance and emission characteristics of a Kirloskar HA394 diesel engine operated on fish oil methyl esters", Renewable Energy, 35(2009), pp. 355-359.

6. KANDASAMY, A., DB JABARAJ, and M. CHANDRAN. "INVESTIGATION OF BIODIESEL (JETROPHA) WITH AL2O3 IN CI 
ENGINE." International Journal of Mechanical and Production Engineering Research and Development (IJMPERD)8. 4, Aug 2018, 961-970

7. Ozer Can, "Combustion characteristics, performance and exhaust emissions of a diesel engine fuelled with a waste cooking oil biodiesel mixture”, Energy Conversion and management, 87(2014), pp. 676-686.

8. Suresh kumar K et al., "Performance and exhaust emission characteristics of a CI engine fuelled withPongamiapinnata methyl ester (PPME) and its blends with diesel", Renewable Energy, 33(2008), pp. 2294-2302.

9. Mallikappa, D. N., et al., "Performance and emission characteristics of double cylinder CI engine operated with cardanol biofuel blends", Renewable Energy, 38 (2011), 1, pp.150-155.

10. Santhanakrishnan, S. and Ramani, B. K. M., "Evaluation of diesel engine performance using diesel - cashew nut shell oil blends", International Journal of Ambient Energy, 38 (2015), 1, pp. 104-107.

11. Bhaskar, K., et al. "Effect of dimethoxy-methane (C3H8O2) additive on emission characteristics of a diesel engine fueled with biodiesel." International Journal of Mechanical and Production Engineering Research and Development 8.1 (2018): 399-406.

12. Azad, A. K., et al., "Mustard oil, an alternative Fuel: An experimental investigation of Biodiesel properties with and without Trans-esterification reaction", Global Advanced Research Journal of Engineering, Technology and Innovation, 1 (2012), 3, pp. 75-84.

13. Sriram, V., et al. "Engine Performance and Emission Characteristics of 1-Octanol Blended Bio-diesel in a Single Cylinder Diesel Engine." Stroke 2000 (2017): 110. International Journal of Mechanical and Production Engineering Research and Development (IJMPERD) 7. 6, Dec 2017, 623-630

14. Aydin, H., et al., "Emissions from an Engine Fuelled with Biodiesel-kerosene Blends", Energy Sources Part A: Recovery, Utilizationand Environmental Effects, 33 (2015), pp. 130-137.

15. Natesan, N. K., “The Enhancement of the Performance of a Biodiesel Operated Diesel Engine”, Energy Sources, Part A: Recovery, Utilization and Environmental Effects, 35 (2013), pp. 1648- 1656. 

